\title{
Changes in Prooxidant and Antioxidant Enzymes and Reduction of Chilling Injury Symptoms during Low-temperature Storage of 'Fuyu' Persimmon Treated with 1-Methylcyclopropene
}

\author{
Zhengke Zhang and Yu Zhang \\ College of Horticulture, Northwest A\&F University, Yangling, Shaanxi \\ Province 712100, PR China
}

\author{
Donald J. Huber \\ Horticultural Sciences Department, P.O. Box 110690, IFAS, University of \\ Florida, Gainesville, FL 32611-0690
}

\begin{abstract}
Jingping Rao ${ }^{1}$, Yunjing Sun, and Shanshan Li
College of Horticulture, Northwest A\&F University, Tai-Cheng Rd. 3\#, Yangling, Shaanxi Province 712100, PR China
\end{abstract}

Additional index words. persimmon, chilling injury, ethylene, 1-methylcyclopropene, polyphenol oxidase, superoxide dismutase

\begin{abstract}
Fuyu' perisimmon fruit were treated with $500 \mathrm{~nL} \cdot \mathrm{L}^{-1} 1$-methylcyclopropene (1-MCP) for $24 \mathrm{~h}$ at $20^{\circ} \mathrm{C}$ and then stored at $4{ }^{\circ} \mathrm{C}$ for 45 days to investigate the effects of 1-MCP on chilling injury (CI) during storage at $4{ }^{\circ} \mathrm{C}$. Persimmon fruit developed CI, manifested as rapid softening and external and internal browning. Injury symptoms were reduced by 1-MCP treatment. 1-MCP also delayed increases in respiration and ethylene production. Compared with control fruit, 1-MCP-treated fruit exhibited increased superoxide dismutase and catalase activities within the initial storage period and lower membrane permeability, malondialdehyde content, and peroxidase and polyphenol oxidase activities throughout the entire storage period. These results suggest that reduction of CI symptoms in persimmon fruit in response to 1-MCP treatment may be attributed to altered oxidative status.
\end{abstract}

Persimmon (Diospyros kaki L. cv. Fuyu) is a crop of high economic importance in northwest China. The fruit is susceptible to chilling injury (CI) during postharvest storage, developing symptoms at 0 to $4{ }^{\circ} \mathrm{C}$ that increase in severity with longer storage (Woolf et al., 1997). The symptoms become most severe after transferring fruit to ambient temperature, rendering the fruit unmarketable (Collins and Tisdell, 1995; MacRea, 1987; Sargent et al., 1993). CI in persimmon fruit is expressed as enhanced softening, browning of skin and flesh, flesh gelling, and loss of flavor (MacRea, 1987). There are several physiological changes occur in parallel with CI in persimmon. For example, MacRea (1987) demonstrated that ethylene production and respiration rates in-

Received for publication 23 July 2010. Accepted for publication 18 Aug. 2010.

Zhengke Zhang and Yu Zhang contributed equally to this work.

This research was supported by the National Natural Science Foundation of China (30771756).

${ }^{1}$ To whom reprint requests should be addressed; e-mail raojingping@hotmail.com. creased rapidly along with appearance of CI symptoms after transfer from low temperature to ambient conditions. Beede (1983) noted that CI was enhanced in persimmon fruit by exposure of fruit to $1 \mu \mathrm{L} \cdot \mathrm{L}^{-1}$ or higher ethylene at $20{ }^{\circ} \mathrm{C}$ before cold storage at 5 to $7^{\circ} \mathrm{C}$. These findings indicate that ethylene contributes to the symptomatology of CI in persimmon (Park and Lee, 2005).

Other researchers have proposed that development of specific CI symptoms might result from imbalances in cellular oxidative metabolism involving oxidative enzymes, including peroxidase (POD) and polyphenol oxidase (PPO) (Hershkovitz et al., 2005). Oxidative stress could also be promoted by the presence of excess reactive oxygen species (ROS) that induce peroxidation and breakdown of unsaturated fatty acids in membrane lipids (Sevillano et al., 2009). A role for disturbances in redox homeostasis in development of CI in persimmon is indirectly supported by the report of Lee et al. (1993), in which antioxidant (diphenylamine) treatment reduced the incidence of skin browning and inhibited softening in 'Fuyu' persimmon fruit during storage at $0{ }^{\circ} \mathrm{C}$.
1-Methylcyclopropene (1-MCP), a potent inhibitor of ethylene action (Sisler, 2006), can maintain quality by suppressing ripening and senescence in a wide range of horticultural crops (Blankenship and Dole, 2003; Huber, 2008; Watkins, 2008). 1-MCP has been reported to reduce CI symptoms of coldstored 'Fuyu' (Girardi et al., 2003; Kim and Lee, 2005; Krammes et al., 2006) and 'Rojo Brillante' (Pérez-Munuera et al., 2009; Salvador et al., 2004) persimmon accompanying with delay of softening. Delay of softening during storage at ambient temperature $\left(20^{\circ} \mathrm{C}\right)$ in persimmon treated with $1-\mathrm{MCP}$ has been correlated with inhibition of cell wall-degrading enzymes (Luo, 2004; Xu et al., 2004). Ultrastructural analysis indicated that reduction of CI in 1-MCP-treated 'Rojo Brillante' persimmon was associated with maintenance of cell wall integrity and intercellular adhesion (Pérez-Munuera et al., 2009). Although it is clear that some CI symptoms are alleviated by suppression of ethylene action, to our knowledge, there have been no attempts at addressing whether the amelioration of CI symptoms through suppression of ethylene action is accompanied by parallel changes in the oxidative metabolism of persimmon.

The objective of this study was to determine whether prestorage 1-MCP application could enhance tolerance to $\mathrm{CI}$ in 'Fuyu' sweet persimmon fruit during low-temperature storage $\left(4^{\circ} \mathrm{C}\right)$. The study specifically addressed the effects of inhibition of ethylene action on changes in the oxidant and antioxidant system, including membrane permeability, membrane lipid peroxidation, and activities of prooxidant (POD and PPO) and antioxidant enzymes [superoxide dismutase (SOD) and catalase (CAT)].

\section{Material and Methods}

Plant material. Sweet persimmon fruit (Diospyros kaki L. cv. Fuyu) with $\approx 70 \%$ of surface yellow coloration (ripening initiated) were obtained from a persimmon orchard in Yangling, Shaanxi province on the day of harvest and transported to the postharvest facilities in Northwest A\&F University within $12 \mathrm{~h}$. Fruit of uniform size without mechanical damage were selected for the experiments.

1-Methylcyclopropene treatment. 'Fuyu' Persimmon fruit were divided into two groups, 300 fruit per group. The two groups were separately placed in two 360-L chambers and one chamber exposed to gaseous 1-MCP $\left(500 \mathrm{~nL} \cdot \mathrm{L}^{-1}\right)$ for $24 \mathrm{~h}$ at $20^{\circ} \mathrm{C}$. The second group of persimmon without exposure to 1-MCP was regarded as the control. 1-MCP gas was released from a commercial powdered formulation (Rohm and Haas Inc., China, a.i. $0.14 \%)$. 1-MCP powder $(0.29 \mathrm{~g})$ was placed in a $25-\mathrm{mL}$ flask with septa followed by injecting $5 \mathrm{~mL} \mathrm{KOH} \mathrm{(2 \% ).} \mathrm{The} \mathrm{sealed} \mathrm{flask}$ containing 1-MCP was transferred into the 360-L chamber and opened before immediately sealing the chamber. After $24 \mathrm{~h}$, the chambers were opened and the fruit transferred to 
storage facilities at $4 \pm 0.5^{\circ} \mathrm{C}$, relative humidity $90 \%$ to $95 \%$. During low-temperature storage, CI was monitored every $5 \mathrm{~d}$ as described subsequently.

Chilling injury incidence and chilling injury index. CI incidence, expressed in percentage, is defined as the ratio of chillinginjured persimmon fruit's number to all fruit's number in each treatment. CI index was visually assessed from skin browning and surface lesion and expressed as a percentage of affected surface area in which $0=$ no injury (no browning or lesions), $1=$ slight (less than $25 \%$ of surface area), $2=$ moderate $(25 \%$ to $50 \%$ of surface area), $3=$ severe ( $50 \%$ to $75 \%$ of surface area), and $4=$ extremely severe (greater than $75 \%$ of surface area). The CII was determined with the formula: $\mathrm{CII}=(0 \times$ $\left.\mathrm{P}_{0}+1 \times \mathrm{P}_{1}+2 \times \mathrm{P}_{3}+3 \times \mathrm{P}_{3}+4 \times \mathrm{P}_{4}\right) /(4 \times \mathrm{N})$ in which $\mathrm{P}_{0}-\mathrm{P}_{4}=$ number of fruit in each CI scale and $\mathrm{N}=$ total number of fruit.

Firmness. Firmness was determined using the firmness detector with an 8-mm diameter stainless steel probe (FT327; Effegi, Italy). For each treatment, two measurements were carried out at two equidistant points on the equatorial axis of 10 fruit. Skin was removed before firmness measurements. The maximum force generated during probe travel (0.5-cm depth of penetration) was used for data analysis. Firmness was expressed as $\mathrm{kg} \cdot \mathrm{cm}^{-2}$. Firmness measurement was performed at $4{ }^{\circ} \mathrm{C}$.

Respiration and ethylene production. Five fruit from each treatment were individually placed in 3.6-L sealed glass jars for $1 \mathrm{~h}$ at $4{ }^{\circ} \mathrm{C}$, after which gas samples $(1 \mathrm{~mL})$ were collected with a syringe. Respiration rate was determined with an infrared $\mathrm{CO}_{2}$ analyzer (Telaire 7001, USA). Ethylene was determined by injecting a gas sample into a flame ionization detection gas chromatograph (Shodex GC-14A, Japan). The oven, detector, and injector were operated at 100,120 , and $120^{\circ} \mathrm{C}$, respectively. The carrier gas $\left(\mathrm{N}_{2}, \mathrm{H}_{2}\right.$, and air) flow rates were 30,30 , and $300 \mathrm{~mL} \cdot \mathrm{min}^{-1}$, respectively. Respiration rate and ethylene production are expressed as $\mu \mathrm{g} \cdot \mathrm{kg}^{-1} \cdot \mathrm{s}^{-1}$ and $\mathrm{ng} \cdot \mathrm{kg}^{-1} \cdot \mathrm{min}^{-1}$, respectively.

Cell membrane permeability. Conductivity measurements $\left(\mathrm{L}_{\mathrm{t}} / \mathrm{L}_{0}\right)$ were used as an index of membrane permeability (Santos et al., 2001). Fruit were processed into small discs $(\approx 0.1 \mathrm{~cm}$ thick, $1.0 \mathrm{~cm}$ diameter $)$ and washed three times with deionized water. After quickly wiping dry with filter paper, the discs $(\approx 2.0 \mathrm{~g})$ were placed in flasks with $30 \mathrm{~mL}$ deionized water. The flasks were shaken on a rotary shaker at $25^{\circ} \mathrm{C}$ for $30 \mathrm{~min}$ and the electrical conductivity (EC) $\left(\mathrm{L}_{\mathrm{t}}\right)$ of the solution was measured using a conductivity meter. The flasks with solution were then heated at $100{ }^{\circ} \mathrm{C}$ for $15 \mathrm{~min}$, quickly cooled, and the EC of the solution measured again $\left(\mathrm{L}_{0}\right)$. Three independent samples derived from three fruit of each treatment were used at each measurement interval.

Malondialdehyde determination. Malondialdehyde (MDA) content was determined by the method of Hodges et al. (1999) with some modifications. One gram of fruit flesh without skin was homogenized in $5 \mathrm{~mL}$ of $5 \%$ (w/v) 2-thiobarbituric acid (TCA). The homogenate was centrifuged at $20,000 \times g$ at $4{ }^{\circ} \mathrm{C}$ for $10 \mathrm{~min}$. One milliliter of supernatant was precipitated with $4 \mathrm{~mL} \mathrm{20 \%}$ TCA containing $0.5 \%(\mathrm{w} / \mathrm{v})$ TCA. The mixture was heated in a water-bath shaker at $95{ }^{\circ} \mathrm{C}$ for $30 \mathrm{~min}$ and quickly cooled in an ice bath. The absorbance was read at $532 \mathrm{~nm}$ after centrifugation at $10,000 \times g$ for $10 \mathrm{~min}$ and the value for nonspecific absorption at $600 \mathrm{~nm}$ was subtracted. The MDA content was calculated using its extinction coefficient of $155 \mathrm{~mm}^{-1} \cdot \mathrm{cm}^{-1}$ and the data expressed as $\mathrm{mmol} \cdot \mathrm{g}^{-1}$ fresh weight (FW). Three independent samples derived from three fruit for each treatment were used at each measurement interval.

Enzyme assay. Ten grams of fruit flesh without skin from three fruits, with three replicates, for each treatment were homogenized with $25 \mathrm{~mL} 100 \mathrm{~mm}$ cold sodium phosphate, $\mathrm{pH} 6.4$, containing $0.5 \mathrm{~g}$ of polyvinyl polypyrrolidone. The homogenate was centrifuged at $27,000 \times g$ at $4{ }^{\circ} \mathrm{C}$ for $20 \mathrm{~min}$.
The supernatant was collected for enzyme assay. POD and PPO activities were assayed according to the methods of Jiang et al. (2002). For POD activity, $0.5 \mathrm{~mL}$ of enzyme in $2 \mathrm{~mL}$ substrate $(8 \mathrm{~mm}$ guaiacol in $100 \mathrm{~mm}$ sodium phosphate, $\mathrm{pH}$ 6.4) was incubated at $30{ }^{\circ} \mathrm{C}$ for $5 \mathrm{~min}$. The reaction was started by addition of $1 \mathrm{~mL}$ of $\mathrm{H}_{2} \mathrm{O}_{2}(24 \mathrm{~mm})$ to the mixture, and the increase in absorbance at 470 $\mathrm{nm}$ was measured for $120 \mathrm{~s}$. PPO activity was measured by incubating $0.5 \mathrm{~mL}$ of the enzyme extract in $3 \mathrm{~mL}$ of buffered substrate (100 mm catechol, $100 \mathrm{~mm}$ sodium phosphate, $\mathrm{pH}$ 6.4) and monitoring the change of absorbance at $398 \mathrm{~nm}$ for $60 \mathrm{~s}$. The activity of POD and PPO was expressed as $\mathrm{U}_{470}$ and $\mathrm{U}_{398}$, in which $\mathrm{U}_{470}=0.01 \Delta \mathrm{A}_{470} \mathrm{~g}^{-1} \mathrm{FW} / \mathrm{min}$ and $\mathrm{U}_{398}=0.01 \Delta \mathrm{A}_{398} \mathrm{~g}^{-1} \mathrm{FW} / \mathrm{min}$. SOD activity was analyzed according to the method of Dhindsa et al. (1981) with some modifications. The reaction mixture $(3 \mathrm{~mL})$ contained $50 \mathrm{~mm}$ sodium phosphate ( $\mathrm{pH} 7.8)$, $13 \mathrm{~mm}$ methionine, $75 \mu \mathrm{M}$ nitroblue tetrazolium (NBT), $10 \mu \mathrm{M}$ EDTA, $2 \mu \mathrm{M}$ riboflavin,
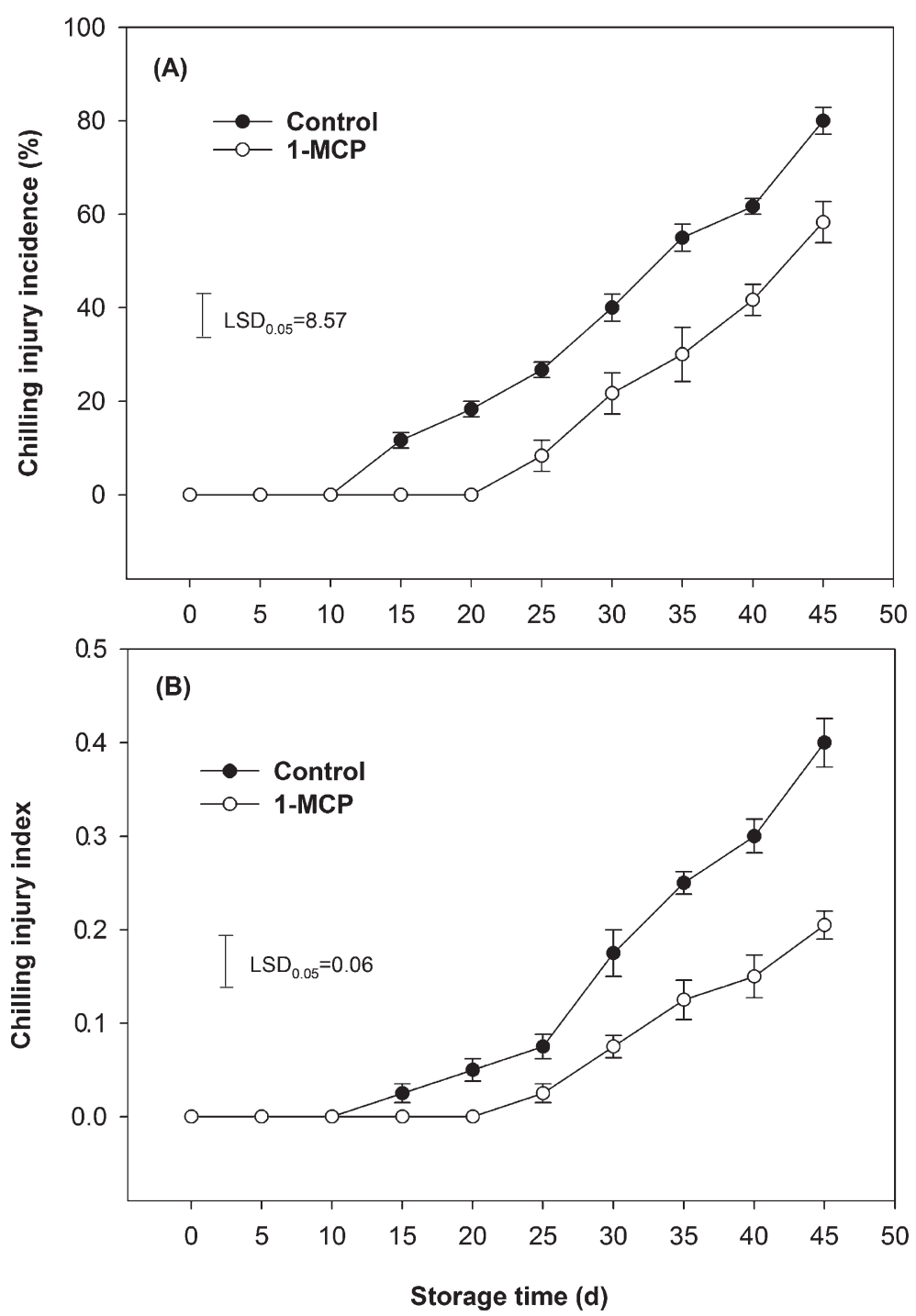

Fig. 1. Chilling injury (CI) incidence (A) and CI index (B) of 'Fuyu' persimmon fruit treated with $500 \mathrm{~nL} \cdot \mathrm{L}^{-1} 1$-methylcyclopropene during storage at $4{ }^{\circ} \mathrm{C}$. Values are the means $\pm \mathrm{SE}$ of three replicates of 20 fruit each treatment. Vertical bars represent the SES of the means. 
and $0.1 \mathrm{~mL}$ enzyme extract. The mixtures were illuminated using a fluorescent lamp (60 $\mu \mathrm{mol} \cdot \mathrm{m}^{-2} \cdot \mathrm{s}^{-1}$ ) for $10 \mathrm{~min}$. SOD activity was determined based on inhibition of reduction of nitroblue tetrazolium. The absorbance was monitored at $560 \mathrm{~nm}$. One unit of activity is the amount of extract that gives $50 \%$ inhibition of the reduction rate of NBT. Specific SOD activity is expressed as $\mathrm{U} \cdot \mathrm{g}^{-1} \mathrm{FW} / \mathrm{h}$. Determination of CAT activity was performed according to the method of Wang et al. (2004) with slight modifications. The reaction mixture consisted of $2 \mathrm{~mL}$ of sodium phosphate, $\mathrm{pH} 7.0,0.5 \mathrm{~mL} \mathrm{H}_{2} \mathrm{O}_{2}(40 \mathrm{~mm})$, and $0.5 \mathrm{~mL}$ enzyme. The decomposition of $\mathrm{H}_{2} \mathrm{O}_{2}$ was measured by the decrease in absorbance at $240 \mathrm{~nm}$. The activity of CAT was expressed as $\mathrm{U}_{240}$, in which $\mathrm{U}_{240}=$ $0.1 \Delta \mathrm{A}_{240} \mathrm{~g}^{-1} \mathrm{FW} / \mathrm{min}$.

Statistical analysis. Data were subjected to repeated-measures analysis of variance (ANOVA) using SAS statistical software (Version 8; SAS Institute, Cary, NC). Fisher's least significant differences $(P \leq$ 0.05 ) were determined to compare differences between means after a significant ANOVA effect. Data are presented as the mean \pm SEM.

\section{Results}

Chilling injury. CI symptoms in this study included surface browning, water-soaking and pitting (external) and flesh browning, softening, and gelling (internal). CI of control 'Fuyu' persimmon was not evident within the initial $10 \mathrm{~d}$ of low-temperature storage. Thereafter, CI incidence and CI severity of control fruit increased with longer storage life (Fig. 1). CI was strongly suppressed in fruit treated with 1-MCP with the CI incidence and CI index remaining at $0 \%$ through $20 \mathrm{~d}$ of storage. From 25 through $45 \mathrm{~d}$ storage at $4{ }^{\circ} \mathrm{C}$, CI incidence and $\mathrm{CI}$ index of 1-MCP-treated fruit averaged $44 \%$ and $48 \%$ lower than that of control fruit, respectively (Fig. 1).

Firmness. The flesh firmness of control persimmon fruit declined rapidly from $15.3 \pm$ 0.85 to $1.0 \pm 0.38 \mathrm{~kg} \cdot \mathrm{cm}^{-2}$ through $25 \mathrm{~d}$ (Fig. $2)$. Fruit treated with 1-MCP exhibited a strong suppression in firmness decline during storage, in which the firmness averaged $85 \%$ higher than that of control fruit from 5 to 25 d of storage. At $45 \mathrm{~d}$, the firmness of 1-MCPtreated fruit had declined to $1.5 \pm 0.63$ $\mathrm{kg} \cdot \mathrm{cm}^{-2}$, a value that was comparable with control fruit at $25 \mathrm{~d}$ (Fig. 2).

Respiration and ethylene production. The respiration rate of control persimmon fruit declined from an initial value of $4.15 \pm 0.12$ to $3.17 \pm 0.18 \mu \mathrm{g} \cdot \mathrm{kg}^{-1} \cdot \mathrm{s}^{-1}$ at $5 \mathrm{~d}$ followed by a sharp increase to a maximum of $5.59 \pm 0.21$ $\mu \mathrm{g} \cdot \mathrm{kg}^{-1} \cdot \mathrm{s}^{-1}$. A 5-d delay in reaching the peak was observed in fruit treated with $500 \mathrm{~nL} \cdot \mathrm{L}^{-1}$ 1-MCP compared with control fruit (Fig. 3A). The respiratory maximum of $4.96 \pm 0.12$ $\mu \mathrm{g} \cdot \mathrm{kg}^{-1} \cdot \mathrm{s}^{-1}$ in $1-\mathrm{MCP}$-treated fruit at $15 \mathrm{~d}$ was $11.2 \%$ lower than that in control fruit at $10 \mathrm{~d}(P<0.05)$. Ethylene production in persimmon fruit at the start of the experiment averaged $1.74 \pm 0.08 \mathrm{ng} \cdot \mathrm{kg}^{-1} \cdot \mathrm{min}^{-1}$. The

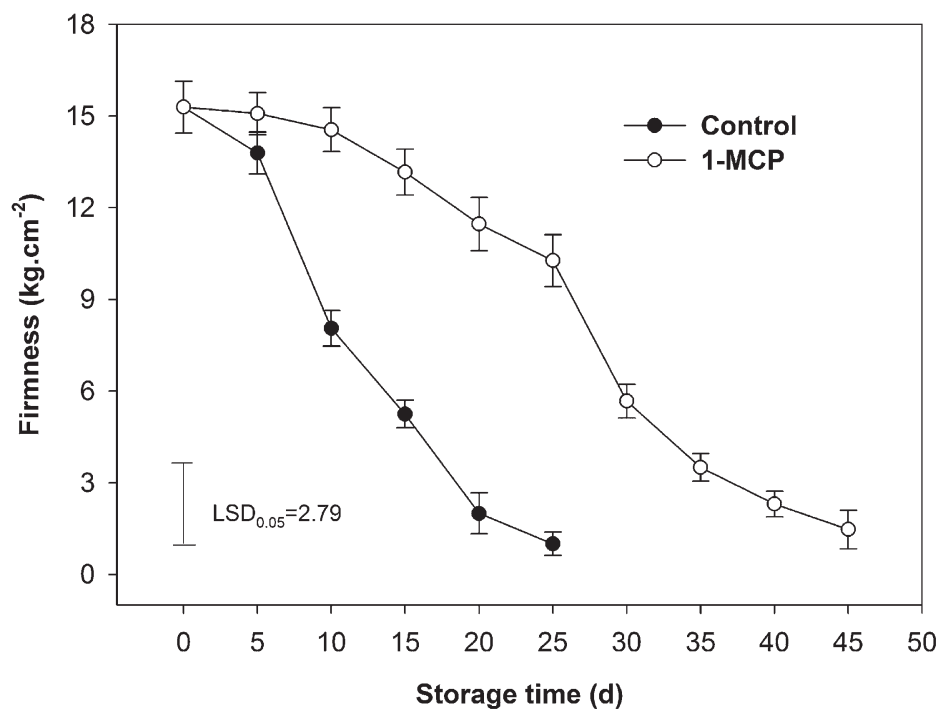

Fig. 2. Firmness of 'Fuyu' persimmon fruit treated with $500 \mathrm{~nL} \cdot \mathrm{L}^{-1} 1$-methylcyclopropene during storage at $4{ }^{\circ} \mathrm{C}$. Values are the means \pm SE of 10 fruit each treatment. Vertical bars represent the SES of the means.
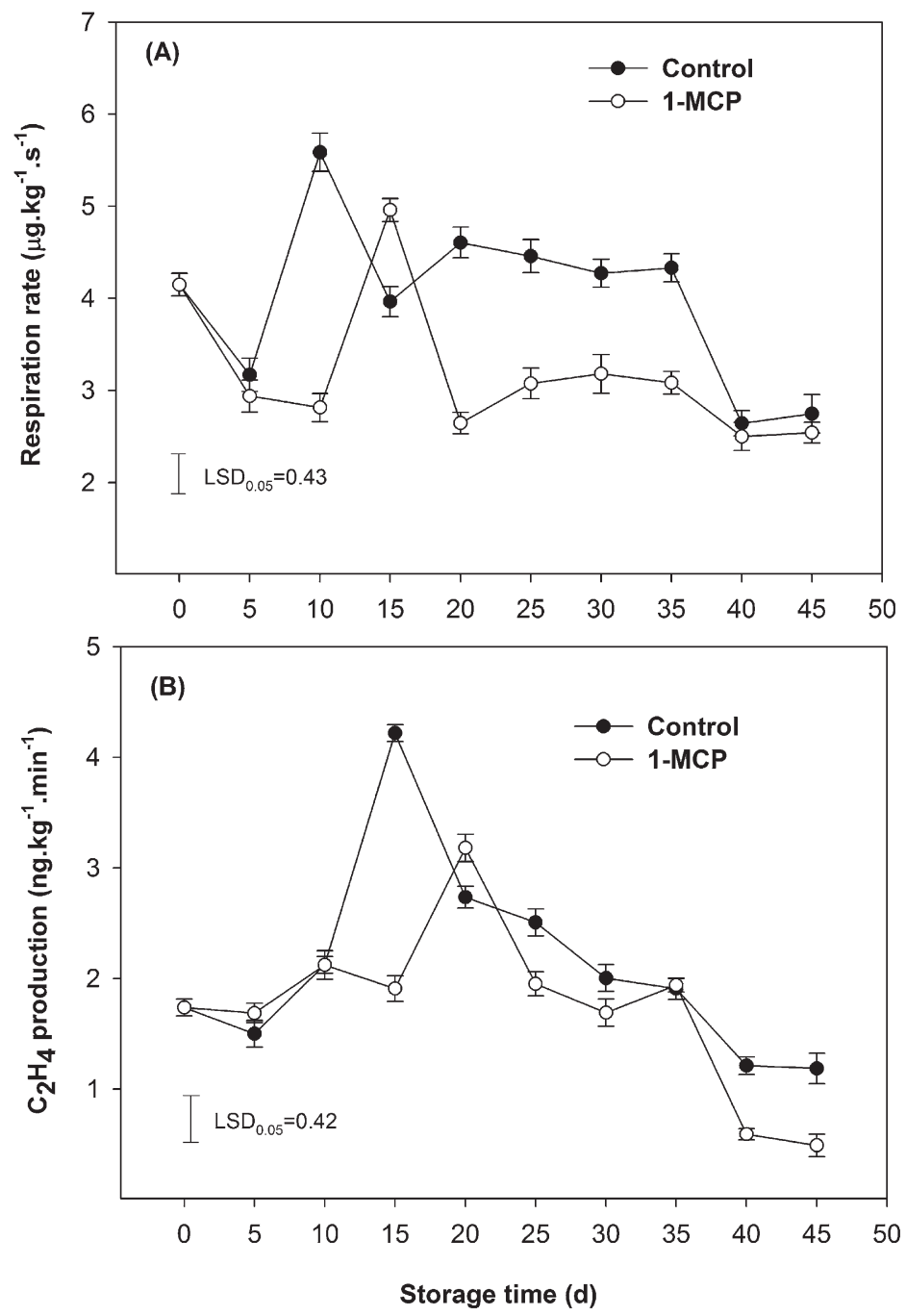

Fig. 3. Respiration (A) and ethylene production (B) of 'Fuyu' persimmon fruit treated with $500 \mathrm{~nL} \cdot \mathrm{L}^{-1}$ 1 -methylcyclopropene during storage at $4{ }^{\circ} \mathrm{C}$. Values are the means \pm SE of five individual fruit. Vertical bars represent the SEs of the means. 
ethylene production changed slowly at similar rates in both control and 1-MCP-treated fruit within the initial $10 \mathrm{~d}$ of low-temperature storage (Fig. 3B). Ethylene production diverged after $10 \mathrm{~d}$ when control fruit increased to a maximum of $4.22 \pm 0.08 \mathrm{ng} \cdot \mathrm{kg}^{-1} \cdot \mathrm{min}^{-1}$ at $15 \mathrm{~d}$ followed by a steady decline as fruit ripened. In contrast to control fruit, a strong suppression of ethylene production was observed in 1-MCP-treated fruit with the maximum delayed to $20 \mathrm{~d}$ with rates reaching to $3.18 \pm 0.12 \mathrm{ng} \cdot \mathrm{kg}^{-1} \cdot \mathrm{min}^{-1}$ (Fig. 3B).

Membrane permeability and malondialdehyde content. Membrane permeability in control persimmon fruit showed a rapid increase within $25 \mathrm{~d}$ of cold storage from an initial value of $14.3 \%$ to $32.5 \%$ at $25 \mathrm{~d}$ followed by maintaining a stable level through the end of storage (Fig. 4A). Fruit treated with 1-MCP exhibited lower membrane permeability, averaging $17 \%$ lower than that of control fruit from 10 to $35 \mathrm{~d}$ of storage.

The initial MDA content in persimmon fruit was $3.36 \pm 0.25 \mathrm{mmol} \cdot \mathrm{g}^{-1} \mathrm{FW}$ and no difference in MDA content was found between control and 1-MCP treatments during the first
$15 \mathrm{~d}$ of low-temperature storage. Thereafter, MDA levels in control fruit increased with only a slow gradual rise noted for 1-MCPtreated fruit. MDA levels in 1-MCP-treated fruit averaged 35\% lower than those of control fruit from 20 to $45 \mathrm{~d}$ of storage (Fig. 4B).

Peroxidase, polyphenol oxidase, superoxide dismutase, and catalase activities. POD activity in control fruit increased continuously during the first $30 \mathrm{~d}$ of low-temperature storage and then slightly declined (Fig. 5A). PPO activity in control fruit showed a sharp increase within the initial $15 \mathrm{~d}$ of storage and subsequently declined through $45 \mathrm{~d}$ to values comparable with those noted at the beginning of storage (Fig. 5B). 1-MCP treatment suppressed increases in POD and PPO activities with activities averaging $47 \%$ and $19 \%$ lower, respectively, than control fruit during low-temperature storage (Fig. 5AB). SOD activity in control fruit gradually increased during the initial period of lowtemperature storage and then declined after 15 d (Fig. 5C). 1-MCP-treated fruit exhibited enhanced SOD activity from $10 \mathrm{~d}$ through $15 \mathrm{~d}$, at which time activity was $18.9 \%$ and $50.9 \%$ $(P<0.05)$ higher than control fruit at 10 and
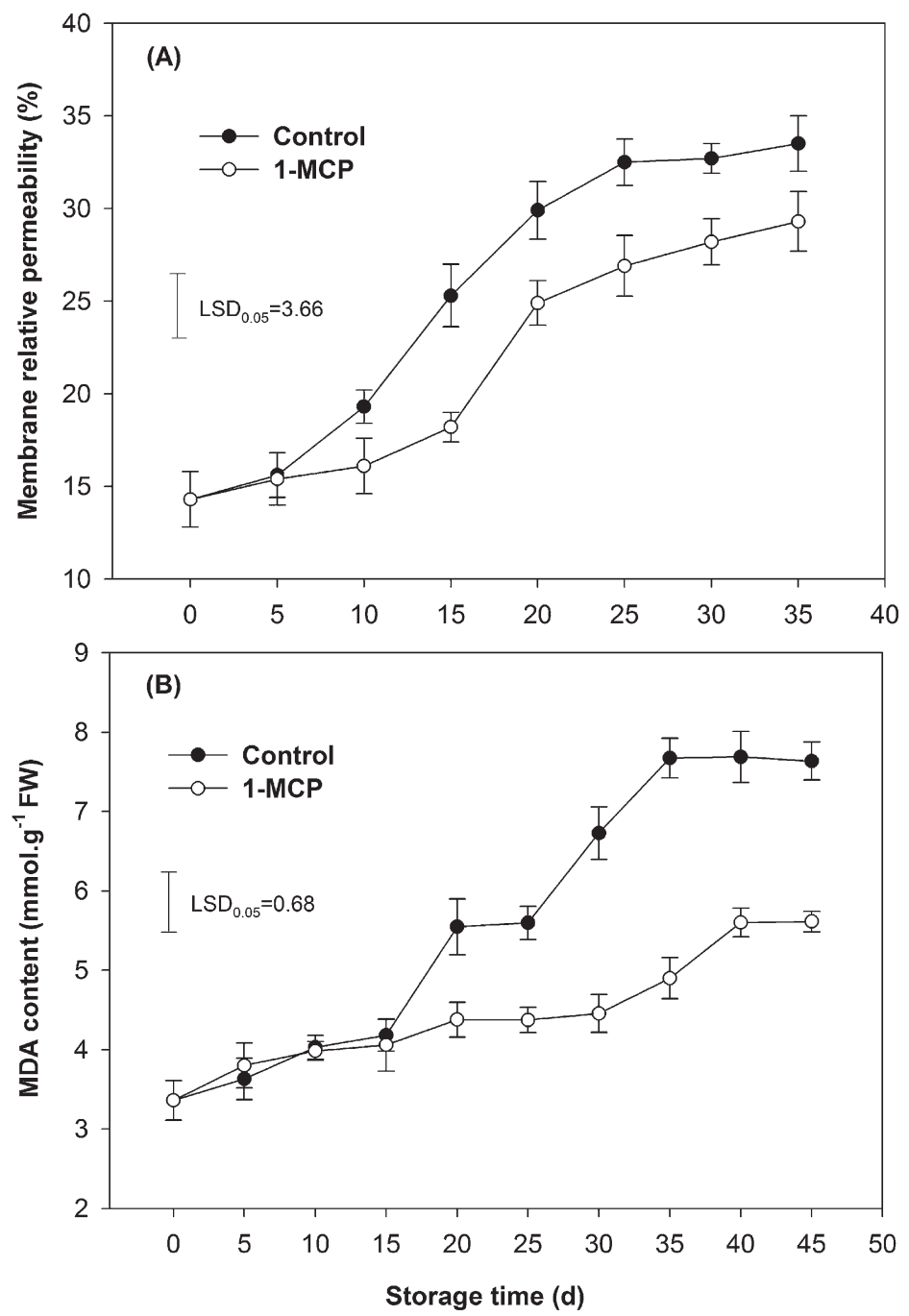

Fig. 4. Cell membrane permeability (A) and malondialdehyde content (B) of 'Fuyu' persimmon fruit treated with $500 \mathrm{~nL} \cdot \mathrm{L}^{-1} 1$-methylcyclopropene during storage at $4{ }^{\circ} \mathrm{C}$. Values are the means \pm SE of triplicate assays. Vertical bars represent the SES of the means.
$15 \mathrm{~d}$, respectively. After $20 \mathrm{~d}$, SOD activity in control and 1-MCP-treated fruit was comparable and steadily declined through $45 \mathrm{~d}$ (Fig. $5 \mathrm{C})$. The trend of CAT activity in control fruit paralleled that observed for SOD activity (Fig. 5D). CAT activity in 1-MCP-treated fruit was higher than that in control fruit during the first $15 \mathrm{~d}$, significantly from 10 to $15 \mathrm{~d}$. At $20 \mathrm{~d}$ and thereafter, CAT activity steadily declined and levels were comparable in control and 1-MCPtreated fruit (Fig. 5D).

\section{Discussion}

The effect of 1-MCP on CI in 'Fuyu' persimmon fruit during low-temperature $\left(4{ }^{\circ} \mathrm{C}\right)$ storage was investigated. The results showed that 1-MCP effectively reduced external browning development and skin lesions, the typical CI symptoms in persimmon fruit (MacRea, 1987). Furthermore, 1-MCP significantly suppressed softening and delayed the respiration and ethylene production peaks (Figs. 2 and 3). By comparison, 'Fuyu' persimmon fruit stored under ambient temperature $\left(20{ }^{\circ} \mathrm{C}\right)$ exhibit respiration and ethylene peaks at 15 and $20 \mathrm{~d}$ of storage, respectively (data not shown). Ethylene biosynthesis along with CI has been correlated to increases in 1-aminocyclopropane-1carboxylic acid (ACC) content and activities of ACC synthase (ACS) and ACC oxidase (ACO) (Wang, 1986). The data provide evidence that CI symptoms in persimmon could be alleviated by suppression of ethylene action. These findings are consistent with reports for 1-MCP effects on CI symptoms in avocado (Woolf et al., 2005) and plum (Candan et al., 2008). In contrast to these results, others observed more severe CI symptoms in 1-MCP-treated nectarines, peaches, and banana (Dong et al., 2001; Fan et al., 2002; Jiang et al., 2004). Enhanced CI symptoms brought about in response to 1MCP treatment were associated with inhibition of transcript accumulation for ACO and abnormal ethylene levels (Dong et al., 2001). It is indicated that the differences relate to whether usual expression of CI is associated with inhibition of ripening (Watkins, 2006).

A further explanation for chilling tolerance in 1-MCP-treated persimmon fruit in our study may result from the reduced membrane permeability and MDA content during cold storage (Fig. 4). The correlation between reduced membrane permeability and lower CI incidence has been demonstrated in hot air-treated astringent persimmon fruit (cv. Bianhua) (Luo et al., 2007). MDA, a thiobarbituric acid-reactive substance resulting from oxidative damage to membrane lipids, has been regarded as a direct indicator of membrane injury (Dhindsa et al., 1981). The extent of membrane lipid peroxidation depends on the severity of cold stress and is highly correlated to the extent of CI (Imahori et al., 2008). Similar results of 1-MCP effect in inhibiting the increase of MDA content have been reported in mango fruit (Singh and Dwivedi, 2008) and broccoli florets (Yuan et al., 2010) stored under ambient temperature. 


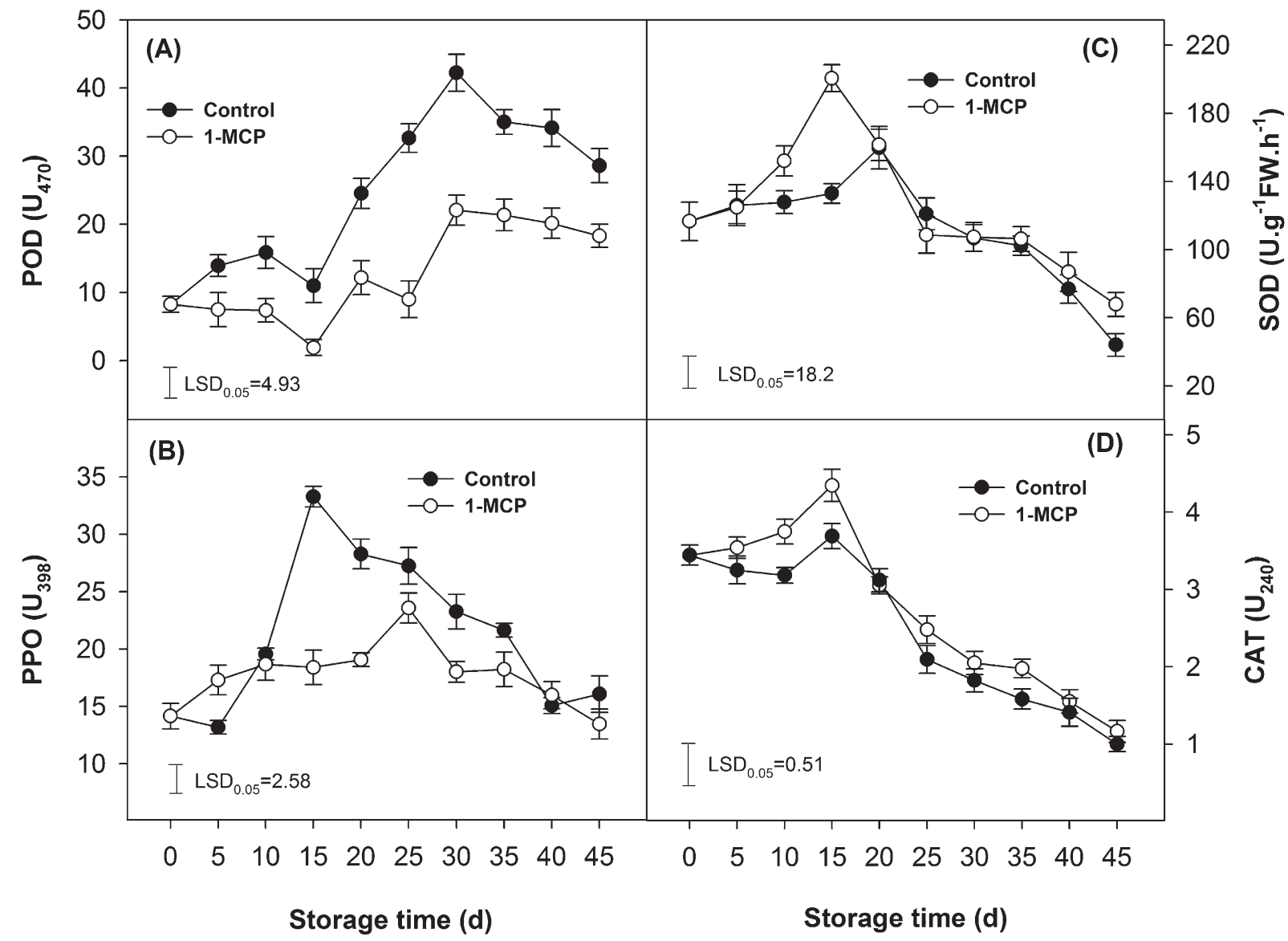

Fig. 5. Peroxidase (A), polyphenol oxidase (B), superoxide dismutase $(\mathbf{C})$, and catalase (D) activities of 'Fuyu' persimmon fruit treated with 500 nL· $\mathrm{L}^{-1}$ 1 -methylcyclopropene during storage at $4{ }^{\circ} \mathrm{C}$. Values are the means \pm SE of triplicate assays. Vertical bars represent the sEs of the means.

Browning as a symptom of CI in persimmon fruit involves oxidation of phenolic substrates mediated by PPO (Mayer, 1987; Tomas-Barberan and Espin, 2001). POD, which catalyzes single-electron oxidation of diverse antioxidant compounds in the presence of hydrogen peroxide, is also a candidate enzyme for browning of fruits and vegetables (Tomas-Barberan and Espin, 2001), and the involvement of POD in the oxidation of phenolic compounds cannot be excluded. The present study showed that POD and PPO activities were significantly suppressed by 1-MCP treatment in persimmon fruit during storage at $4{ }^{\circ} \mathrm{C}$ (Fig. 5A-B). By inhibiting ethylene action, the deterioration of cell membrane occurring in response to low-temperature storage was significantly reduced. We speculate that the maintenance of membrane integrity in 1-MCP-treated fruit contributed to the reduction in skin and flesh browning by preserving cell compartmentation and separation of PPO and POD enzymes and phenolic substrates. The idea is supported by a report that flesh browning in 1-MCP-treated $\left(300 \mathrm{~nL} \cdot \mathrm{L}^{-1}\right)$ avocado fruit stored under low temperature $\left(5^{\circ} \mathrm{C}\right)$ was associated with reduced PPO and POD activities (Hershkovitz et al., 2005).

Much evidence supports the idea that lowtemperature stress increases the production of ROS including $\mathrm{O}_{2}^{-}$, singlet oxygen, $\mathrm{H}_{2} \mathrm{O}_{2}$, and hydroxyl radical (Sevillano et al., 2009).
Oxidative stress from disproportionate increases in ROS likely contributes to the development of CI symptoms (Scandalios, 1993). Prevention of oxidative injury is crucial to cell survival under chilling stress and is considered to be a major mechanism for tolerance against low-temperature injury. It has been confirmed that some antioxidant enzymes including SOD, CAT, and ascorbate peroxidase (APX) play important roles in controlling metabolism of ROS (Sala, 1998; Zheng et al., 2008). By the action of SOD, $\mathrm{O}_{2}^{-}$is converted to $\mathrm{H}_{2} \mathrm{O}_{2}$; subsequently, $\mathrm{H}_{2} \mathrm{O}_{2}$ is efficiently decomposed by CAT and APX (Mittler, 2002). It has been reported that a number of postharvest treatments may improve chilling tolerance and reduce CI in harvested horticultural crops by enhancing activities of antioxidant enzymes (Cao et al., 2009; Wang, 1995). In the present study, SOD and CAT activity were significantly enhanced in 1-MCP-treated fruit in the early stages of low-temperature storage (Fig. 5CD). The data imply that SOD and CAT might contribute to the 1-MCP-mediated delay and alleviation of CI symptoms in 'Fuyu' persimmon fruit.

In summary, our results show that 1-MCP treatment can effectively enhance chilling tolerance and reduce CI symptoms in 'Fuyu' sweet persimmon during storage at $4{ }^{\circ} \mathrm{C}$. The reduction in CI by 1-MCP is possibly related to its effect at preserving membrane integrity, as indicated by a significant reduction in MDA content. Improvement of chilling tolerance by 1-MCP may also involve reduced levels of prooxidative enzymes (POD and PPO) and enhanced levels of antioxidant enzymes (SOD and CAT).

\section{Literature Cited}

Beede, R.H. 1983. The storage performance of the Fuyu persimmon and its susceptibility to chilling injury. MSc thesis, University of California-Davis, Davis, CA

Blankenship, S.M. and J.M. Dole. 2003. 1-Methylcyclopropene. A review. Postharvest Biol. Technol. 28:1-25.

Candan, A.P., J. Graell, and C. Larrigaudiereb. 2008. Roles of climacteric ethylene in the development of chilling injury in plums. Postharvest Biol. Technol. 47:107-112.

Cao, S., Y. Zheng, K. Wang, P. Jin, and H. Rui. 2009. Methyl jasmonate reduces chilling injury and enhances antioxidant enzyme activity in postharvest loquat fruit. Food Chem. 115:1458-1463.

Collins, R.J. and J.G. Tisdell. 1995. The influence of storage time and temperature on chilling injury in Fuyu and Suruga persimmon (Diospyro kaki L.) grown in subtropical Australia. Postharvest Biol. Technol. 6:149-157.

Dhindsa, R.S., P. Plumb-Dhindsa, and T.A. Thorpe. 1981. Leaf senescence: Correlated with increased levels of membrane permeability and lipid peroxidation, and decreased levels of superoxide dismutase and catalase. J. Expt. Bot. 32:93-101.

Dong, L., H.W. Zhou, L. Sonego, A. Lers, and S. Lurie. 2001. Ethylene involvement in the 
cold storage disorder of 'Flavortop' nectarine. Postharvest Biol. Technol. 23:105-115.

Fan, X., L. Argenta, and J.P. Mattheis. 2002. Interactive effects of 1-MCP and temperature on 'Elberta' peach quality. HortScience 37:134 138.

Girardi, C.L., A. Parussolo, R. Danieli, A.R. Corrent, and C.V. Rombaldi. 2003. Conservation of persimmons fruit (Diospyros kaki L.) cv. Fuyu with application of 1-methylcyclopropene Revista Brasileira de Fruticultura. Jaboticabal, SP. 25:54-56 [in Portuguese with English abstract].

Hershkovitz, V., I. Sam, S.I. Saguy, and E. Pesis. 2005. Postharvest application of 1-MCP to improve the quality of various avocado cultivars. Postharvest Biol. Technol. 37:252264.

Hodges, D.M., J.M. Delong, C.F. Forney, and R.K. Prange. 1999. Improving the thiobarbituric acid-reactive-substances assay for estimating lipid peroxidation in plant tissues containing anthocyanin and other interfering compounds. Planta 207:604-611.

Huber, D.J. 2008. Suppression of ethylene responses through application of 1-methylcyclopropene: A powerful tool for elucidating ripening and senescence mechanisms in climacteric and nonclimacteric fruits and vegetables. HortScience 43:106-111.

Imahori, Y., M. Takemura, and J. Bai. 2008. Chilling-induced oxidative stress and antioxidant responses in mume (Prunus mume) fruit during low temperature storage. Postharvest Biol. Technol. 49:54-60.

Jiang, A.L., S.P. Tian, and Y. Xu. 2002. Effects of controlled atmospheres with high $\mathrm{O}_{2}$ or high $\mathrm{CO}_{2}$ concentrations on postharvest physiology and storability of 'Napoleon' sweet cherry. Acta Bot. Sin. 44:925-930.

Jiang, W., M. Zhang, J. He, and L. Zhou. 2004. Regulation of 1-MCP-treated banana fruit quality by exogenous ethylene and temperature. Food Sci. Technol. Int. 10:15-20.

Kim, Y.K. and J.M. Lee. 2005. Extension of storage and shelf-life of sweet persimmon with 1-MCP. Acta Hort. 685:165-174.

Krammes, J.G., L.C. Argenta, and M.J. Vieira. 2006. Influences of 1-methylcyclopropene on quality of persimmon fruit cv. 'Fuyu' after cold storage. Acta Hort. 727:513-518.

Lee, S.K., I.S. Shin, and Y.M. Park. 1993. Factors involved in skin browning of non-astringent 'Fuyu' persimmon. Acta Hort. 343:300-303.
Luo, Z.S. 2004. Effect of 1-methylcyclopropene on persimmon fruit ripening and pectin metabolism. J. Fruit Sci. 21:229-232.

Luo, Z.S., X.L. Xu, Z.Z. Cai, and Y.F. Xi. 2007. Relationships between heat shock alleviating chilling injury and active oxygen metabolism in persimmon fruit. Transactions of the Chinese Society of Agriculture 23:249-252 [in Chinese with English abstract].

MacRea, E.A. 1987. Development of chilling injury in New Zealand grown Fuyu persimmon during storage. N. Z. J. Exp. Agr. 15:333-344.

Mayer, A.M. 1987. Polyphenol oxidases in plantsRecent progress. Phytochemistry 26:11-20.

Mittler, R. 2002. Oxidative stress, antioxidants and stress tolerance. Trends Plant Sci. 7:405-410.

Park, Y.M. and Y.J. Lee. 2005. Ripening responses of 'Fuyu' persimmon fruit to exogenous ethylene and subsequent shelf temperature. Acta Hort. 685:151-156.

Pérez-Munuera, I., I. Hernando, V. Larrea, C. Besada, L. Arnal, and A. Salvador. 2009. Microstructural study of chilling injury alleviation by 1-methylcyclopropene in persimmon. HortScience 44:742-745.

Sala, J.M. 1998. Involvement of oxidative stress in chilling injury in cold-stored mandarin fruits. Postharvest Biol. Technol. 13:255-261.

Salvador, A., L. Arnal, A. Monterde, and J. Cuquerella. 2004. Reduction of chilling injury symptoms in persimmon fruit cv. Rojo Brillante by 1-MCP. Postharvest Biol. Technol. 33:285291.

Santos, C.L., A. Campos, H. Azebedo, and G. Caldeira. 2001. In situ and in vitro senescence induced by $\mathrm{KCl}$ stress: Nutritional imbalance, lipid peroxidation and antioxidant metabolism. J. Expt. Bot. 52:351-360.

Sargent, S.A., T.E. Grocker, and J.J. Zoellner. 1993. Storage characteristics of 'Fuyu' persimmons. Proc. of the Florida State Horticultural Society 106:131-134.

Scandalios, J.G. 1993. Oxygen stress and superoxide dismutases. Plant Physiol. 101:7-12.

Sevillano, L., M.T. Sanchez-Ballesta, F. Romojaroc, and F.B. Floresc. 2009. Physiological, hormonal and molecular mechanisms regulating chilling injury in horticultural species. J. Sci. Food Agr. 89:555-573.

Singh, R. and U.N. Dwivedi. 2008. Effect of ethrel and 1-methylcyclopropene (1-MCP) on antioxidants in mango (Mangifera indica var. Dashehari) during fruit ripening. Food Chem. 111: 951-956.
Sisler, E.C. 2006. The discovery and development of compounds counteracting ethylene at the receptor level. Biotechnol. Adv. 24:357-367.

Tomas-Barberan, F.A. and J.C. Espin. 2001. Phenolic compounds and related enzymes as determinants of quality in fruit and vegetables. J. Sci. Food Agr. 81:853-876.

Wang, C.Y. 1986. Effect of temperature and light on ACC and MACC in chilled cucumber seedlings. Sci. Hort. 30:47-52.

Wang, C.Y. 1995. Effect of temperature preconditioning on catalase, peroxidase and superoxide dismutase in chilled zucchini squash. Postharvest Biol. Technol. 5:67-76.

Wang, Y.S., S.P. Tian, Y. Xu, G.Z. Qin, and H.J. Yao. 2004. Changes in the activities of pro- and anti-oxidant enzyme in peach fruit inoculated with Cryptococcus laurentii or Penicillium expansum at $0{ }^{\circ} \mathrm{C}$ or $20^{\circ} \mathrm{C}$. Postharvest Biol. Technol. 34:21-28.

Watkins, C.B. 2006. The use of 1-methylcyclopropene (1-MCP) on fruits and vegetables. Biotechnol. Adv. 24:389-409.

Watkins, C.B. 2008. Overview of 1-methylcyclopropene trials and uses for edible horticultural crops. HortScience 43:86-94.

Woolf, A.B., C. Requejo-Tapia, K.A. Cox, R.C. Jackman, A. Gunson, and M.L. Arpaia. 2005. 1-MCP reduces physiological storage disorders of 'Hass' avocados. Postharvest Biol. Technol. 35:43-60.

Woolf, A.B., K.J. Spooner, M. Lay-Yee, I.B. Ferguson, C.B. Watkins, and S.K. Forbes. 1997. Reduction of chilling injury in the sweet persimmon 'Fuyu' by hot air heat treatments. Postharvest Biol. Technol. 11:155-164.

Xu, C.G., A. Nakatsuka, and H. Itamura. 2004. Effects of 1-methylcyclopropene (1-MCP) treatment on ethylene production, softening and activities of cell wall degrading enzymes in 'Saijo' persimmon fruit after removal of astringency with dry ice. J. Jpn. Soc. Hort. Sci. 73: 184-188 [in Japanese with English abstract].

Yuan, G., B. Sun, J. Yuan, and Q. Wang. 2010. Effect of 1-methylcyclopropene on shelf life, visual quality, antioxidant enzymes and healthpromoting compounds in broccoli florets. Food Chem. 118:774-781.

Zheng, Y.H., W.M.F. Raymond, S.Y. Wang, and C.Y. Wang. 2008. Transcript levels of antioxidative genes and oxygen radical scavenging enzyme activities in chilled zucchini squash in response to superatmospheric oxygen. Postharvest Biol. Technol. 47:151-158. 